\title{
Wrocławska synagoga „Pod białym bocianem” i jej genetyczne uwarunkowania
}

C dy jest mowa o architekturze Wrocławia XIX stulecia, to synagoga należy do dzieł znaczących. Choć jej pierwotny wygląd - zwłaszcza wnętrza - w trakcie kolejnych modernizacji (w roku 1872/3, następnie w 1905, 1929 i w latach 1998-2008) uległ znacznym przeobrażeniom, jeszcze dzisiaj zadziwia swoim eleganckim, a zarazem reprezentacyjnym image'em. Na jej wyjątkowy charakter po raz z pierwszy zwrócił uwagę Harold Hammer-Schenk, w swojej pracy omawiającej budowle synagogalne w Niemczech wzniesione pomiędzy 1780 i 1933 rokiem. Według tego badacza wrocławska synagoga swoją klasycystyczną stylistyką wpisuje się w krag najwybitniejszych dzieł pierwszej połowy XIX wieku. Przy czym genezę jej powstania wiąże z prowadzoną wówczas w Berlinie polityką rządu, który starał się poprzez budowę pierwszej wspólnej dla całej gminy synagogi zapewnić sobie możliwość kontroli nad życiem religijnym i społecznym wspólnoty żydowskiej we Wrocławiu1. Trzeba bowiem wyjaśnić, że w tradycyjnej strukturze gminy żydowskiej, szczególnie niezbyt licznej, życie jej całej społeczności koncentrowało się w synagodze. Ponadto ortodoksyjny judaizm wymaga trzykrotnego codziennego udziału w modlitwie, a wrocławska społeczność

1 H. Hammer-Schenk, Synagogen in Deutschland. Geschichte einer Bangattung im 19. und 20. Jahrbundert, Hamburg 1981, s. 56-57. 
gminy w tym czasie raczej wierna była tradycji. Miejsce zamieszkania i pracy zatem nie powinno być odległe od miejsca modlitwy ${ }^{2}$. Jeżeli natomiast chodzi o jej klasycyzującym image, to zadaniem Hammer-Schenka również w tym przypadku zadecydowała konserwatywna postaw członków wspólnoty, preferujących formy klasycystyczne. Najpewniej wybór tych właśnie „Formen des Rundbogenstils” winien był podkreślać związek gminy z państwem pruskim ${ }^{3}$.

Kilka lat później do ustaleń Hammer-Schenka nawiązała Carol Herselle-Krinsky w pracy dotyczacej budownictwa synagogalnego w Europie. W pracy tej, poza obszernym opisem budynku nie pojawiły się jednak żadne nowe ustalenia. Następnym autorem, którego zainteresowały losy i architektura wrocławskiej synagogi był Jerzy Krzysztof Kos, który w artykule z roku 1991 ustosunkował się do kwestii genezy wrocławskiej synagogi w kontekście historii wrocławskiej gminy żydowskiej. Artykuł wrocławskiego historyka sztuki niewątpliwie przyczynił się do bardziej skrupulatnego uchwycenia dziejów powstania budowli. Najważniejsze jednak, że Kos - kontynuując badania Ludwiga Burgemeistra i Güntera Grundmanna starał uzasadnić przyjęta przez nich tezę, że autorem projektu synagogi był działający wówczas we Wrocławiu architekt Carl Ferdinand Langhans ${ }^{5}$. Jest bowiem znamienne, że we wcześniejszych pracach wzmiankujących synagoge „Pod białym bocianem” za jej twórcę uznawano żydowskiego malarza Rafaela Biona (1773-1836) ${ }^{6}$. Kos w swoich rozważaniach wiążących autorstwo projektu z osobą Langhansa oparł się na memoriale gminy z 1819 roku, obecnie przechowywanym w zbiorach ŻIH. Z dokumentów tych wynika, że projekt budowli miał być przygotowany w urzędzie Miejskiej Deputacji Budowlanej, którym od maja 1819 roku kierował Carl Ferdinand. Kiedy rozpoczęto prace nad wznoszeniem, rezydujący we Wrocławiu architekt udał się w swoją druga Grande Tour - do Francji i Włoch, prace

2 Por. E. Bergman, „Nie Masz Bóżnicy Powsžechnej”. Synagogi i domy modlitwy w Warszawie od końca XVIII do poczqteu XXI wieku, Warszawa 2007, s. 73.

3 Por. Hammer-Schenk, op. cit., s. 57.

4 J. K. Kos, Synagoga „Pod Biatym Bocianem” we Wroctawiu, „Sobótka”, 2, 1991, s. 191-203.

5 L. Burgemeister, G. Grundmann, Die Kunstdenkmäler der Stadt Brteslau, Breslau 1934, s. $157 \mathrm{i} \mathrm{n}$.

6 Por. F. Nosselt, Breslau und dassen Umgebungen, Breslau 1833, s. 57. 
zaś wszczęte przez niego kontynuowali najpierw Carl Wilhelm Schindler, a po jego śmierci budowniczy Johann Gottfried Tschocke? ${ }^{7}$ Kos wskazując, że źródeł formalnych dla wrocławskiej synagogi należałoby poszukiwać z jednej strony w ukształtowanym w Niderlandach w ciagu XVII wieku modelu budownictwa synagogalnego; z drugiej zaś - w protestanckim budownictwie sakralnym, wyraźnie przychyla się do koncepcji zaprezentowanej przez Helen Rosenau w jej obszernym artykule zamieszczonym w ,Journal of the Warburg and Courtland Institutes" i nie wykracza poza ustalenia autorki, która pisze, że ten typ synagogi był wyrazem postaw asymilacyjnych i miał wspólne korzenie z XVII-wieczną tradycją budownictwa sakralnego. Analogicznie do Rosenau, Kos twierdzi, że: „Źródłem tym była antyczna bazylika, znana z rekonstrukcji A. Palladia, która przetworzona w hugenockim zbiorze w Charenton (1622-1623) silnie oddziaływała na budownictwo środowiska żydowskiego w Amsterdamie. Pod wpływem tych wzorców wzniesiono w latach 1671-1675 synagogę sefardyjską, rozpoczynając szereg podobnych realizacji w Holandii, później w Anglii. Wspólnymi cechami tych budowli były trójnawowe układy przestrzenne na rzucie prostokąta, z emporami i wyodrębnionymi niszami na szafy ołtarzowe w ścianach wschodnich ${ }^{8}$.

Architektura wrocławskiej synagogi zaprezentowana została również w artykule z roku 1997, omawiającym Langhansowskie budowle sakralne zaprojektowane w latach 20. XIX wieku we Wrocławiu. Autorka poprzez analizę formalna trzech projektów: kościoła pw. Jedenastu Tysięcy Dziewic (1819-1822), kaplicy Maryjnej na Osobowicach (1823-1824) i synagogi „Pod białym bocianem” (1829) starała się wykazać ogromny wpływ, jaki na ówczesną twórczość Langhansa syna wywarly projekty Friedricha Gilly’ego i architektów rewolucyjnych z kręgu Ledoux-Boullée?

O ile związanie dzieł Langhansa młodszego z silnym oddziaływaniem nań principiów architektów rewolucyjnych nie budzi dzisiaj sprzeciwu, to

J. K. Kos op. cit., s. 196-198; por. też. Archiwum Państwowe, Akta Miasta Wrocławia 1794, kart. 81, 82.

8 J. K. Kos, op. cit., s. 201; por. też H. Rosenau, The Synagogue and Protestant Church Architecture, ,Journal of the Warburg and Courtauld Institutes", t. 4, 1941, s. 81-82.

9 Por. B. Grzegorczyk, Idea a realizacja. Uwagi o koncepiji architektonicznej trzech wroctawskich budowli Carla Ferdinanda Langhansa, „Rocznik Wrocławski”, 4, 1997, s. 297-316. 
przyjęte przez Kosa ustalenia autorstwa Rosenau, jak i związanie formalnej genezy wrocławskiej synagogi z budowlami z Charenton i Amsterdamem - poniekąd słuszne - wzbudzaja jednak pewien niedosyt. Mimo woli pojawia się bowiem pytanie o drogę, którą te inspiracje miałyby wpływać na kształt architektoniczny synagogi „Pod białym bocianem”. Bądź co bądź - zarówno Charenton, jak i Amsterdam należą do miejsc dość odległych od stolicy śląskiej prowincji. Bezpośrednio z owym problemem łączy się druga kwestia, a mianowicie na ile architektoniczny projekt wpisywał się w ogólną koncepcję budownictwa synagogalnego, postrzeganego przecież jako „budowla króla Salomona”.

Nie ulega wattpliwości, że historia wzniesienia tej tak ważnej dla wspólnoty wrocławskich Żydów budowli kwestii tej nie wyjaśnia. Oddana do użytku w roku 1829 synagoga była w pewnym sensie efektem kompromisu zawartego między polityka prowadzona przez państwo pruskie a żydowskim społecznością Wrocławia. Chociaż represyjne nakazy wprowadzone po zajęciu Śląska przez Prusy obowiązywały do roku 1812, czyli do czasu wydania edyktu emancypacyjnego, to trzeba pamiętać, że niektóre z wcześniejszych nakazów obowiązywały nadal. Do nich należały m.in. wprowadzenie płatnych koncesji na urządzanie i prowadzenie bóżnic oraz opłaty podatkowe od miejsc kultu. W dalszym ciagu dostęp do stanowisk w administracji publicznej oraz urzędach był dla Żydów zamknięty lub bardzo utrudniony. Znamiennym przykładem - jak pisze Leszek Ziątkowski - „było wchodzenie Żydów do lokalnego samorządu we Wrocławiu. W pierwszych po wprowadzeniu nowego prawa miejskiego w 1808 r. wyborach do rady miejskiej Żydzi stanowili 5\% wyborców, co mniej więcej odpowiadało ich procentowemu udziałowi w ludności miasta. Nie wybrano jednak wówczas żadnego przedstawiciela Żydów do zgromadzenia" ${ }^{10}$. Tak więc, mimo że podatki z bóżnic wpływające do kasy państwowej przysparzały dochodów podatkowych, to jednak władze państwowe były dość sceptycznie nastawione do dużej liczby bóżnic prywatnych, które mogły wymykać się spod kontroli państwa. O czym najlepiej świadczy reskrypt ministra śląska Carla Georga von Hoyma z 1790 roku, którego \} 1 4 \text { zapowiadał, że }

10 L. Ziątkowski, Drieje Żydów we Wrockawiu, Wrocław 2000, s. 47. 
władze wyrażą zgodę na wzniesienie dużej publicznej synagogi w zamian za likwidację bóżnic ukrytych w różnych zakamarkach miasta. Jednak obawiając się ingerencji państwa w sprawy kultu, Żydzi nie zdecydowali się na porzucenie swoich miejsc kultu. Do sprawy tej władze pruskie wróciły po kilkudziesięciu latach w roku 1819, żądając zamknięcia wszystkich bóżnic, które nie uzyskały ważnych koncesji i wzniesienia dużej synagogi, służącej wszystkim członkom gminy. Jednak i tym razem społeczność żydowska zajęła stanowisko negatywne, motywując odmowę brakiem funduszy, które umożliwiłyby wzniesienie takiej synagogi. Jak pisze Kos: „Odpowiedzią na pismo gminy był ponowne, stanowcze zażądanie niezwłocznego przystapienia do budowy synagogi i ukończenia jej w ciagu dwóch lat" ${ }^{\prime 1}$. W ten sposób zainicjowana wśród członków gminy akcja mająca na celu zbiórkę pieniędzy na rzecz wzniesienia synagogi zakończyła się fiaskiem. Po raz kolejny sprawa odżyła w 1826 roku, a jej inicjatorami byli członkowie założonego w 1780 roku „Towarzystwa Braterskiego”. Dzierżawili oni na swoje potrzeby niewielką bóżnicę Zum Tempel, której prawo użytkowania wygasło w 1817 roku. W tej sytuacji nader pilną sprawą było stworzenie nowego miejsca modlitw. Kontrakt o dzierżawę udało się jednak odnowić, więc sprawę budowy nowej synagogi ponownie zarzucono. Niebawem jednak do niej powrócono i w roku 1820 w tym celu zakupiono działkę od Jacoba Silbersteina. Do prac budowlanych przystapiono w 1927 roku i po dwóch latach 23 kwietnia 1829 roku zakończono proces budowy uroczystym poświęceniem synagogi.

Synagoga wzniesiona została na terenie Starego Miasta w obrębie dzielnicy żydowskiej, na dziedzińcu otoczonym zabudowa. Takie usytuowanie - w głębi posesji - uwarunkowane było bez wątpienia chęcią ukrycia budynku, ale także wynikało z tradycji judaizmu ${ }^{12}$. Mimo to budynek, wyłaniający się ponad dachami piętrowej zabudowy, sprawiał wrażenie monumentalnego i wyjątkowego, tak iż nie sposób było go pomylić z budowlami prywatnymi. Decydowała o tym nie tylko jego skala, proporcje, ale także sposób opracowania. Architekt zaprojektował budowlę na rzucie umiarowego prostokąta z dwoma pozornymi ryzalitami - stosunkowo

11 J. K. Kos, op. cit., s. 195.

12 Por. przypis 2. 
nieznacznie wysuniętym po stronie południowej i bardziej wydatnym od wschodu. Do zachodniej elewacji przylegał długi wąski przedsionek, nieznacznie tylko odsunięty od sąsiedniej zabudowy. W oparciu o ten prosty rzut powstał kubiczny blok, w partiach naroży ujęty masywnymi, boniowanymi lizenami. Oba ryzality zostały zaakcentowane przez przyścienne portyki utworzone przez kanelowane pilastry i zwieńczone trójkątnymi naczółkami. Tak uformowany korpus w całości i pokryty poziomym boniowaniem nakrywał niski czterospadowy dach ukryty za ścianka attyki. $\mathrm{Na}$ jego szczycie wznosiła się wieloboczna latarnia. Elewację północną i południowa artykułował ciag niezwykle smukłych okien arkadowych. Oba portyki w szczególny sposób podkreślały wysoce reprezentacyjny charakter budowli, ponieważ dekoracja kapiteli pilastrów nie stanowi żadnego z klasycznych porządków. Artysta zastosował w ich dekoracji motywy orientalne - stylizowane liście palmy. Owe archaizowane formy dekoracji architektonicznej pojawiły się zapewne we wnętrzu. Do wnętrza zapewniały dostęp dwa wejścia: w fasadzie (od południa), które służyło podczas uroczystości, i w elewacji zachodniej - używane w dniu powszednie. Wejście południowe, poprzedzone trzema stopniami, które ujmowały z dwóch stron wysokie postumenty z ustawionymi nań wyobrażeniami sów, mimo skromnej oprawy architektonicznej, miało charakter reprezentacyjny. Jednonawowe wnętrze otrzymało formę obszernej prostokątnej sali nieco zagłębionej w stosunku do przedsionka i nakrytej sklepieniem nieckowym. Od południa zachodu i północy wnętrze to obiegały dwie kondygnacje empor, wspartych na dwunastu kolumnach, z których dwie od wschodu wraz z parapetem empor tworzyły monumentalną serlianę, w centrum której umieszczono Aron Ha-Kodesz, gdzie przechowywano Torę. Kapitele kolumn zapewne odpowiadały kapitelom pilastrów z zewnętrznego wystroju architektonicznego budowli.

Nie ulega wątpliwości, że Langhans, jak każdy architekt działający w tym czasie, musiał uwzględnić w swoim projekcie zalecenia zleceniodawców, które były podstawowe dla projektu. Jednak dzisiaj jest trudno określić, jak dalekosiężny wpływ miały one na architekturę, ponieważ w przypadku synagogi nie zachowały się żadne źródła, które moga tłumaczyć projekt, a i sam Langhans nie pozostawił dokumentacji, która mogłaby nam w tym pomóc. Biorąc jednak pod uwagę szczególny typ budowli 
- synagogę - przyjąć należy, że podstawowym odniesieniem, do którego powinny nawiązywać reprezentacyjne wnętrza, było wyobrażenie świątyni króla Salomona. Wiadomo także, że Langhans miał już pewne wyobrażenia na temat tej świątyni z racji, że kilka lat wcześniej wykonał projekt loży „Fryderyk pod złotym berłem” (1816) ${ }^{13}$. Jednak kwestie inspiracji w przypadku wrocławskiej synagogi są o wiele bardziej zagmatwane.

Wprawdzie do świątyni Salomona nawiązywano już w czasach odległego średniowiecza ${ }^{14}$, to wydaje się, że dla niniejszych rozważań istotniejsze znaczenia odegrała epoka nowożytna, stąd istotn3 jest przynajmniej zasygnalizowanie polemiki, jaka toczyła się począwszy od XVII wieku, szczególnie w Republice Niderlandów, odnośnie do dzieł „wzniesionych” przez króla Salomona.

Wiadomo, że już w renesansie studiowanie Witruwiusza zrodziło pytanie: czy jest właściwe używać język klasycznych, pogańskich form dla architektury chrześcijańskiej ${ }^{15}$. Wydaje się, że pierwszym architektem, któremu w umiejętny sposób udało się pogodzić owa pozorną sprzeczność, był Juan Bautista Villalpando (1552-1608). Villalpando bowiem w swoich rozważaniach In: Ezechielem Explanationes et Apparatus Urbis ac Templi Hierosolymitani, opublikowanych w Rzymie pomiędzy 1596 a 1604 rokiem, twierdzil, że klasyczna architektura wywodzi się z boskiej architektury, tak jak to zostało wyrażone Bibliii' ${ }^{16}$. W drugiej części swojego traktatu, ten architekt z kręgu Juana de Herrera, wyjaśnia rozlegle swoja teorię, omawiając biblijną architekturę ze szczególnym uwzględnieniem świątyni Salomona. Należy zaznaczyć, że Villalpando nie rozróżniał świątyni wzniesionej w X wieku p.n.e. od świątyni wzniesionej po wygnaniu babiloński, a trzecią świątynia zniszczoną w 70 roku n.e. i opisaną przez Józefa Flawiusza. Mimo różnic w opisie, w tradycji świątyni Salomona umieścił także świątynię z wizji

\footnotetext{
13 B. Grzegorczyk, Uwag kilka o wroctawskim wolnomularstwie i siedzibie losiy „Fryderyk pod zlotym bertem”,"Quart”, nr 1(27), 2013, s. 19-35.

14 Por. C. H. Krinsky, Representations of the Temple of Jerusalem before 1500, „Journal of the Warburg and Courtauld Institutes", t. 33 , 1970, s. 1-19; także S. Skibiński, Kaplica na Zamku Wysokim w Malborku, Poznań 1982, s. 191-202.

15 Por. L. B. Alberti, Driesiéć Ksiag o budowaniu, Warszawa 1960, ks. VII.

16 Por. B. Evers, C. Thoenes, Théorie de l'archtecture de la renaissance à nos jurs, Köln-London-Los Angeles-Madrid-Paris 2003, s. 366-7.
} 
Ezechiela. Poza świątynią omówił także budowlę pałacu. Pałac składał się z trzech części: domu króla i domu królowej (pałacu) i domu lasu Libanu (hali), który umieszczony został w środku budynku, pomiędzy dwoma dziedzińcami oraz świątynia. Dom ten składał się z dużej sali i znajdującego się za nią osobnego pomieszczenia, gdzie Salomon wydawał wyroki. Z całego kompleksu jedynie ta część ma podane wymiary: 100 łokci wzdłuż, 50 łokci wszerz i 30 łokci wzwyż.

Znamienne, że historia opowiedziana przez Witruwiusza o odkryciu przez Kalimacha porządku korynckiego została umieszczona przez Villalpando w rozwoju biblijnej głowicy, która uprzedziła koryncka, ale zamiast liśćmi akantu ozdobiona była przez liście palmy. Według budowniczego Escorialu wszakże Koryntczycy byli tak zazdrośni o wspaniałość biblijnego kapitelu, że zastąpili liście palmy akantem i przedstawiali to jako swój własny wynalazek ${ }^{17}$.

W przeciwieństwie do teorii architektury, w której książka Witruwiusza odgrywała centralną rolę, dla autora In: Ezechielem Explanationes... Witruwiusz był tylko egzegeta biblijnej architektury, co automatycznie implikowało, że Villalpando mógł korzystać nie tylko z tego, co zostało zapisane w Biblii, ale także ze wszystkich osiagnięć klasycznej architektury. Przy czym tak samo jak dla Witruwiusza, tak dla Villalpando ważna była symetria, a wszystkie wymiary pozostawały w wzajemnych korelacjach, dla których podstawową jednostką miary był moduł.

Jak często architekci zwracali swoje zainteresowania ku biblijnej architekturze, trudno w pełni określić, wiadomo jednak, że znalazła ona szczególne miejsce w rozważaniach niderlandzkich teologów. Wraz z rozprzestrzenianiem się reformacji wzrosło zainteresowanie i znajomość Biblii w Niderlandach. Dodatkowym asumptem były oczywiście także dzieło Józefa Flawiusza Antiquitates Judaicae. Wyjątkowe zainteresowanie dla studiowania architektury biblijnej dało się zauważyć w XVII wieku w środowisku teologów, których przywódca duchowym był Francuz François Vatable. W roku 1630 Constantijn L'Empereur (1591-1648) opublikował

17 Por. P. Vlaardingerbroek, op. cit., s. 69. 
łacińskie tłumaczenie z Miszny, traktatu Middot ${ }^{18}$, w którym podał szczegółowo wymiary świątyni. Dziesięć lat później, ok. 1640 roku, żydowski naukowiec Jacob Jehuda Leon (1602-1675) rozpoczął budowę drewnianego modelu świątyni, który pokazywał u siebie w domu i na miejskich kiermaszach. W 1642 roku ukazała się jego praca Afbeeldinghe van den Tempel Salomonis, kilkakrotnie publikowana i tłumaczona. $\mathrm{Na}$ ile miał on kontakt ze środowiskiem architektów - nie wiadomo, ale kiedy w 1674 roku podją podróż do Anglii, by tam zaprezentować model świątyni, otrzymał polecające listy m.in. do Christophera Wrena ${ }^{19}$.

Do grona badaczy zajmujących się świątynią króla Salomona dołączył także teolog Johannes Coccejus (1603-1669), który oddalił rekonstrukcję Villalpando ponieważ według niego, świątynia z wizji Ezechiela nie jest opisem rzeczywistej budowli, ale przedstawieniem wyższej duchowej rzeczywistości. Przy pomocy matematyka Karela Rechel von Hollenstein i architekta Philipsa Vingboona, przedstawił własny obraz rekonstrukcji świątyni. Owa rekonstrukcja została ostro skrytykowana przez wydawcę i pisarza Wilhelmusa Goeree (1635-1711), który w różnych publikacjach głosił własne poglądy dotyczące świątyni i porządku Salomona.

Swoimi poglądami sprowokował do udziału w dyskusji syna Coccejusa - Johannesa Heinricusa Coccejusa - który powtarzał ustalenia ojca, poszerzając je o własną rekonstrukcję świątyni opartą na pracy Józefa Flawiusza. $\mathrm{Na}$ co Goeree natychmiast zareagował we wstępie do II wydania Algemeene Bounkeunde z 1705 roku.

Istotna rolę w tej dyskusji odegrał także - teoretyk architektury - Nicolaus Goldmann (1611-1665), który nauczał architektury w Lejdzie i wiadomo, że jego pomysły rozszerzały się zarówno w Republice, jak i poza jej granicami. On również był zwolennikiem koncepcji Villalpando ${ }^{20}$.

18 Miszna - wyraz pochodzący od czasownika studiować, ponownie przeglądać, oznacza także pierwszą redakcję żydowskich ustnych tradycji, tzw. „ustna tora”. Miszna składa się z 63 masechtot, czyli traktatów. Middot, traktat w Miszna, X w kolejności omawia rozmiary i układ świątyni; jest podzielony na 5 rodzajów składających się z 34 paragrafów.

19 Por. P. Vlaardingerbroek, op. cit., s. 70.

20 Por. B. Evers . Ch. Thones, op. cit., s. 550-552. 
O tym, że biblijna architektura wzbudzała zainteresowanie także w XVIII stuleciu, świadczy m.in. Bybelsche Mathematicus z 1768 roku $^{21}$ oraz praca Johanna Bernharda Fischera von Erlach Entwurff Einer Historischen Architectur (1721), w której prezentacja architektonicznych dokonań rozpoczyna się od świątyni Salomona w redakcji Villalpando, znanej mu z opisu wspomnianego Nicolausa Goldmanna ${ }^{22}$.

Zasygnalizowanie ożywionej dyskusji, jaka toczyła się XVII wieku wokół problematyki architektury biblijnej w Republice Zjednoczonych Prowincji, wydaje się o tyle istotne, że istnieje kilka przesłanek, które wskazują że Langhansom - ojcu i synowi - problematyka ta była przynajmniej częściowo znana. Informacje te można uwzględnić, gdy wprowadzimy kod biografii obu architektów. Dziad Carla Gotharda, a pradziad Carla Ferdinanda był pastorem ${ }^{23}$ i jako teolog mógł być zainteresowany tym problemem, o czym najpewniej dyskutował ze swoim synem, Gottfriedem (1691-1763), rektorem liceum przy protestanckim Kościele Pokoju w Świdnicy, a zarazem ojcem Carla Gottharda. Wiemy także, że Carl Gotthard był autorem projektów kilku kościołów protestanckich: w Głogowie, Sycowie, Wałbrzychu, Dzierżoniowie oraz Rawiczu i tematyka architektury biblijnej musiała mu być znana. Szczególnie interesująco jawi się w kontekście świątyni Salomona kompozycja fasad czterech z wyżej wymienionych kościołów, w których wejścia flankują dwie potężne kolumny toskańskie. Być może architekt, w ten sposób nawiązał do stojących przed świątynią Salomona słupów: Joachim i Boaz ${ }^{24}$.

Wiemy także, że Langhansa ojca interesowała architektura Niderlandów i w celu jej dokładnego poznania, w trakcie podróży przedsięwziętej do Anglii na przełomie 1775-1776 roku zatrzymał się w kilku miastach

21 J. J. Schmidt, Bybelsche Mathematicus of Schriftuurlijke wiskundige; behelzende eene opheldering der Heilige Schrift, wit de wiskundige wetenschappen. Te weten: de rekenkunde, starrekunde, uurwyzerkunde en gezichtkunde, Amsterdam-Dordrecht 1768.

22 Por. B. Evers , Ch. Thones, op. cit., s. 574-576.

23 Por. W. T. Hinrichs, Carl Gotthard Langhans. Ein Schlesischer Baumeister 1733-1808, Strassburg 1909, s. 1.

${ }^{24}$ J. K. Kos, Carl Gotthard Langhans 1732-1808. Architekt ₹. Kamiennej Góry, Kamienna Góra 2008, s. 23-25, ostatni monografista śląskiej twórczości Carla Gottharda Langhansa skupił uwage na analizie formalnej dzieł i pominą interpretację architektury w aspekcie znaczeniowym. 
Republiki, by lepiej zapoznać się z dokonaniami jej budowniczych ${ }^{25}$. Należy przy tym pamiętać, że architektoniczno-teologiczna dyskusja, która toczyła się tutaj przez dwa stulecia, nie pozostała bez wpływu na ówczesne realizacje kościołów. Wpływom świątyni z Jeruzalem podlegały np. projektowane przez Jacoba van Campen kościoły w Renswoude (1639), Hoge Zwaluwe (1639) i Nieuve Kerk w Haarlemie (1645) oraz ratusz amsterdamski, którego budowę rozpoczęto w $1648^{26}$. Także w pracach Arenta van ,s-Gravesande, ucznia Jacoba van Campen, ujawniają się wpływ biblijnej architektury - budowla Marekerk w Lejdzie (1639) oraz lejdejskie Hofje van Brouchovena ${ }^{27}$. Carl Gotthard zatem, choć zainteresowany był architektura przemysłową Lejdy, najpewniej zapoznał się także z jej założeniami sakralnymi i ich genezą ${ }^{28}$. Budowla Marekerk w Lejdzie jest o tyle istotna, że był to pierwszy kościół protestancki wzniesiony od podstaw w Republice ${ }^{29}$.

Wreszcie wiemy z testamentu tego architekta ${ }^{30}$, że głównym spadkobiercą swojego „warsztatu pracy” uczynił syna - Carla Ferdinanda, twórcę wrocławskiej synagogi. Ów wszedł na mocy testamentu m.in. w posiadanie biblioteki ojca, a także zebranych przez niego rysunków, miedziorytów, obrazów, dalej instrumentów matematycznych, stołu do pracy oraz ubrań. Bez wątpienia w spuściźnie Langhansa ojca zachowały się również prace, które wykonał podczas pobytu w Republice. Jeśli więc Langhans syn nie

25 Ibidem, s. 5.

26 P. Vlaardingerbroek, op. cit., s. 68, 75-93 dokładnie omawia problem odniesień amsterdamskiego ratusza do pałacu Salomona.

27 Por. G. H. P. Steenmeijer, Tot cieraet ende aensien deser stede. Arend van 's-Gravesande, architect en ingenieur (ca. 1610-1662), Leiden 2005, s. 184-187, 218-220.

28 F. Nicolai, Beschreibung der Königlichen Residenzstädte Berlin und Potsdam und aller daselbst befindlicher Merwürdigkeiten, Berlin 1779, s. 148-149; J. J. Volkmann, Neuste Reisen durch die Vereinigten Nidelande vorzüglich im Absicht auf die Kunstsammlungen, Naturgeschichte und Manufacturen..., Leipzig 1783, s. 345; W. Th. Hinrichs, op. cit., s. 32 pisza, że Langhans w trakcie swojego pobytu w Republice odwiedził Amsterdam, Lejdę, Hagę, Delfty, Rotterdam oraz Diemer Meer i Zuidersee, Sardam i Haarlem; także J. K. Kos, op. cit., s. 14 wzmiankuje pobyt architekta w Holandii.

${ }^{29}$ „Mare” - słowo z języka staroniderlandzkiego oznacza: „wieści”, „,wiadomości”, niekoniecznie dobre.

30 Por. J. K. Kos, op. cit., s. 7, który informuje, że testament przechowywany jest w Brandenburgisches Landeshauptarchiv Potsdam, Rep. 4 A, Kammergericht Testamente, Nr 10625. 
znał z autopsji architektury niderlandzkiej, to brak ten rekompensowały szkice i notatki ojca.

Nadmienić należy również, że w czasach, gdy architektowi przypadło wykonanie projektów synagogi - po afrykańskiej kampanii Napoleona - wzrosło zainteresowanie architekturą i sztuką starożytnego Egiptu. Do popularyzacji motywów z tego kręgu przyczyniły się powstające wtedy publikacje francuskie, po części zaś także angielskie, podyktowane pragnieniem obu mocarstw, by tworzyć aluzje podkreślające ich sukcesy militarne odniesione na lądzie i morzu, w Egipcie i na wodach egipskich. Z drugiej strony przypomnieć należy, że ówczesne ideały estetyczne klasycyzmu skłaniały ku prostocie, wielkości i masywności, najpierw przedkładając architekturę starożytnej Grecji, zwłaszcza stylu doryckiego, by następnie sięgnąc po wzorce bardziej w głąb czasu - do budowli starożytnego Egiptu. Wizjonerskie szkice stworzone przez takich architektów jak np. Etienne-Louis Boullée, Claude Nicolas Ledoux czy Friedrich Gilly bardzo często przywoływały formy egipskich monumentów. Choć Langhans posłużył się dekoracją o stylistyce egipskiej - poza synagogą również w domu kupca Friesnera i loży „Fryderyk pod złotym berłem” - to zarówno w przypadku loży, jak i synagogi wydaje się, że wybór tej stylistyki miał zbliżoną genezę i nie była ona wynikiem chwilowej fascynacji sztuką Egiptu ${ }^{31}$. Zwłaszcza istotny jest tutaj sposób wykonania kapiteli, które otrzymały porządek salomonowy. Tego rodzaju kapitele na stałe wpisały się w tradycję budownictwa synagogalnego, o czym świadczy najlepiej fakt, że zastosowane zostały m.in. w projektach z początku XIX stulecia synagogi w Monachium (Jean Baptiste Metivier, 1811) czy synagogi w Kassel (Johann Conrad Bromeis, 1821) oraz w realizacji modernistycznej synagogi w Bratysławie (Artur Szalatnai-Slatinski, 1923-1926).

Nie ulega wątpliwości, że podejmując się wykonania synagogi, Carl Friedrich Langhans na pewno uzyskał pewne wskazówki od inicjatorów przedsięwzięcia, być może właśnie od malarza Rafaela Biowa. Trzeba wszak pamiętać, że Friedrich Noesselt już w roku 1833 pisał w swoim przewodniku po Wrocławiu, iż autorem rysunku, wedle którego wzniesiono

31 Por. B. Grzegorczyk, Pałace - instytucje dziewiętnastowiecznego Wrockawia - znake patronatu obywatelskiego, Toruń 2014, s. 130. 
gmach synagogi był Biow. Architekt mógł też, co z pewnością uczynił, wesprzeć się rekonstrukcją świątyni Salomona przedstawioną w roku 1804 przez Aloisa Hirta bądź zapoznać się z nieco później wydaną na ten temat publikacją Hirta ${ }^{32}$.

Bez wattpienia nie mniej ważny od teoretycznych rozważań jest wątek budowli z Charenton. Przede wszystkim dlatego, że była to budowla istotna zarówno dla protestantów, jak i dla amsterdamskiej społeczności żydowskiej. By w pełni zrozumieć jej znaczący charakter, należy się cofnąć do roku 1598, kiedy to Edykt Nantejski zakazywał budownictwa świątyń protestanckich w odległości 10 mil od Paryża. W kilka lat później paryżanie doprowadzili do wybudowania swojej świątyni na wschód od Paryża w Charenton (1606). Niebawem jednak, w trakcie religijnych zamieszek, hugenocka świątynia została zniszczona. Gdy minęły dwa lata od jej zburzenia, ponownie budowla została odbudowana (1622/23) pod kierunkiem Salomona de Brosse, architekta pochodzącego z prominentnej rodziny francuskich hugenotów ${ }^{33}$. Powstał wówczas, założony na rzucie prostokąta, typowy budynek o długości $33 \mathrm{~m}$ i wysokości 19,5 m. Wnętrze artykułowało dwadzieścia wysmukłych filarów podtrzymujących dwukondygnacyjne empory, rozmieszczone wzdłuż trzech stron budowli. Wydaje się, że świątynia ta dzięki publikacji licznych miedziorytów była stosunkowo dobrze znana w środowiskach protestanckich. Po unieważnieniu Edyktu Nantejskiego w 1685 świątynia została zniszczona. W obliczu niebezpieczeństwa, ciagłych zamieszek o podłożu religijnym wielu hugenotów emigrowało wówczas do Zjednoczonego Królestwa, ale część znalazła schronienie w Berlinie, w którym wówczas panował wielki elektor Fryderyk III, od 1701 roku król Fryderyk I, który edyktem wydanym w Poczdamie zezwolił francuskim protestantom na osiedlenie się w Berlinie. Otrzymali oni również zgodę na budowę własnej świątyni. I tak na Gendarmenmarkt, po jego północnej stronie, wzniesiony został Kościół Francuski wg projektu Louisa Cayarta, oparty na wzorze kościoła w Charenton. W kilkanaście lat później, po stronie południowej placu, wzniesiono identyczny doń Kościół Nie-

\footnotetext{
32 A. Hirt, Der Tempel Salomons, Berlin 1809.

33 Por. R. Coppe, Salomon de Brosse and the Development of the Classical Style in French Archiecture, London 1972.
} 
miecki (1780-1785). Oba te kościoły doskonale znane były ojcu i synowi Langhansom.

Hugenoci, którzy osiedlili się w Zjednoczonym Królestwie, również wznieśli budowle, które służyły im jako miejsca modlitwy. Zarówno w przypadku Amsterdamu, jak i Lejdy ich twórcy wzorowali się na symbolicznej dlań budowli w Charenton. Społeczność Żydów sefardyjskich, która osiedliła się w Amsterdamie, podjęła trud wzniesienia Synagogi Portugalskiej w latach 1671-1675, a więc w szczególnym momencie, gdy trwała tutaj ożywiona dyskusja dotycząca świątyni Salomona ${ }^{34}$. Jednocześnie kulturowa asymilacja, jaka miała miejsce w amsterdamskiej wspólnocie żydowskiej, skłaniała tamtejsze środowisko do tego, by przyjąć za wzór wznoszone wówczas budowle protestanckie, co wyraźnie uwidaczniają zarówno masywne przypory amsterdamskiej synagogi ,inspirowane” budowlami króla Salomona, jak sposób opracowania przeznaczonego do jej wnętrza Aron Ha-Kodesz, przypominającego szafy liturgiczne zborów protestanckich z tego czasu. Prawdopodobnie amsterdamska budowla wpłynęła też na sposób realizacji Wielkiej Synagogi w Londynie, wzniesionej w latach 1788-1790 według projektów Jamesa Spillara. I w ten sposób świątynia Charenton stała się wzorem nie tylko dla protestantów, ale również dla budownictwa kultowego Żydów w Europie. Trudno dzisiaj wyraźnie wskazać jeden asumpt, który byłby szczególnie istotny w przypadku dzieła Carla Ferdinanda Langhansa.

Reasumując niniejsze rozważania, należy podkreślić złożoność problematyki i jej wielowątkowość w kwestii form stylowych, dziś dręcząca badaczy szeregiem watpliwości dotyczących jednoznacznego wskazania na genezę architektoniczną - może być szczególnie ważną wskazówką gdy weźmie się pod uwagę kontekst znaczeniowy dzieła. Wydaje się, że być może owa różnorodność skojarzeń dla architekta stanowiła ważny bodziec, uzasadniający stworzenie takiego dzieła, w którym splatały się wielorakie doświadczenia wiernych reprezentujących różnorodne wyznania, a jednak przyjmujących wespół za idealny wzór świątynię Salomona. Koncepcja taka wpisywało się bardzo dobrze również w ówczesną ideologię masoń-

34 J. F. Van Agt, Synagogen in Amsterdam, s' Gravenhage 1974, s. 36-52. 
ską, z którą architekt, chociażby przez to, że był członkiem loży „Fryderyk pod złotym berłem" musiał być związany, tym bardziej, że był autorem projektu wrocławskiej siedziby loży. Z tym jednak wiąże się kolejny problem. Wiadomo bowiem, że członkowie loży wyjątkowo niechętnie byli nastawieni do przyjęcia w swoje szeregi przedstawicieli wrocławskiej gminy żydowskiej. Langhans był wziętym architektem i cieszył się poważaniem w kręgach wrocławskiej socjety, co nie neguje faktu, że dał się poznać jako koniunkturalista skrzętnie wykorzystujący sprzyjające warunki do robienia własnej kariery. Fakt, że nie zadbał o to, by projekt synagogi „Pod białym bocianem" znalazł się w jego oeuvre nie był bynajmniej spowodowany skromnościa architekta ${ }^{35}$, ale raczej wynikał z chęci pozostania anonimowym twórca, by nie narazić się na ostracyzm we wpływowych kręgach wrocławskiego wolnomularstwa.

\section{Summary}

\section{The Synagogue Unter the White Stork and her genitilty condition}

Synagogue architecture in the 19th century Lower Silesia does not Have its own monograph. Most of the publications concern the Synagogue Under the White Stork in Wrocław, which represents the classical architecture. The neoclassical building was designed by an eminent German architect, Carl Ferdinand Langhans (1781-1869) and opened in 1829. His project presented the Synagogue on the longitudinal plan. The main prayen hall is surrounded on three sides with womens galleries. Two levels of galleries to the north and two on the sout flank single gallery on the eastern Torah ark wall. The orginal interior, now last, was designed by painter Raphael Biow (1773-1836) and his son Hermann Biow (1804-1850).

It is considered a sterling example of 17 th-century Protestant sacralen art (church in Chareton, 1622-1623, Salomon de Brosse) and 17th-century Sephardic synagogue in Amsterdam (1671-75), Ellias Bouvman). The core of this article is an attempt to indicate the genesis of an architectural form of the orginal building. It seems that what influenced most both the architectural form and disposition with their decorations was siscussion led in the 17 th c. in The Republic of the United Provinces. The discussion was aroused both by Villalpando's work and

\footnotetext{
35 Por. A. Zabłocka-Kos, Zrozumieć miasto. Centrum Wrockawia na drodze ku nowoczesnemu city 1807-1858, Wrocław 2006, s. 161.
} 
Josephus Flavius's considerations. As Carl Gotthard Langhans had the opportunity to get acquainted with ame edifices following the pattern of Salomon's Temple (Mareker and Hofje van Broukhoven in Leiden and the town hall in Amsterdam among others) we can presume that he passed this knowledge on his son, who later created the seat of Synagogue Unter the White Stork. 